\title{
Korelasi Kemampuan Menyimak dan Aktifitas Berpidato Terhadap Keterampilan Berbicara Bahasa Arab Bagi Siswa
}

\author{
Ipah Fakhrunnissa \\ Madrasah Aliyah Manba'ul ‘Ulum Cirebon \\ E-mail: ipahfakhrunnissa01@gmail.com \\ Erfan Gazali \\ Institut Agama Islam Negeri (IAIN) Syekh Nurjati Cirebon \\ E-mail: erfangazali@yahoo.com \\ Wawan Arwani \\ Institut Agama Islam Negeri (IAIN) Syekh Nurjati Cirebon \\ E-mail: wawanarwani@gmail.com
}

\begin{abstract}
In everyday life, listening activities cannot be separated from speaking activities. It is impossible for people to listen if no one is talking. Likewise, on the contrary, it is impossible for people to talk without anyone listening. These two activities complement each other and combine into oral communication, such as in conversation, discussion, telephone, question and answer and interview. Speaking skills is one of the types of language skills to be achieved in teaching modern languages including Arabis. The purpose of this study was to determine the extent to which listening skills and speech activities, and their correlation to the ability to speak Arabic in class XI of the Department at Social Sciences (IPS) of MA Manba'ul 'Ulum Dukupuntang-Cirebon. The type of research used in this study is ex-post-facto research, while the method used in this study is a quantitative method with a descriptive-correlational design. The population is all students at class XI of MA Manba'ul 'Ulum DukupuntangCirebon which amounted to 100 students. While the sample technique is Probability Sampling in the form of Cluster Random Sampling which is class XI IPS which amounts to 20 students. Data collection is obtained through unstructured tests and interviews. The data analysis technique uses the normality test and hypothesis test. The results of the research are: (1) there is a positive and significant correlation between listening ability and student's speaking ability with a calculated $r_{\text {value }}$ greater than rable $(0,769>0,4438)$ and a significance value of $0,000<0,5$ so Ho is rejected; (2) there is a positive and significant correlation between speech activities with student's speaking ability with a calculated $r_{\text {value }}$ greater than rable $(0,786>0,4438)$ and a significance value of $0,000<0,5$ so Ho is rejected; (3) there is a positive and significant correlation between listening ability and speech activitiy with student's speaking ability with a calculated $r_{\text {value }}$ greater than $r_{\text {table }}(0,822>0,4438)$ and a significance value of
\end{abstract}


0,000 which means less than $0,05(0,000<0,5)$ then Ho is rejected. That is, that there is a correlation between listening ability and speech activities with speaking ability. Thus, listening skills and speech activities have an important role in improving student's speaking skils.

\section{Keywords: Correlation, Listening Ability, Speech Activity, Speaking Ability}

\section{Abstrak}

Kegiatan menyimak tidak dapat dipisahkan dengan kegiatan berbicara dalam kehidupan sehari-hari. Tidak mungkin orang menyimak jika tidak ada orang yang berbicara. Begitu pula sebaliknya, tidak mungkin orang berbicara tanpa ada yang menyimak. Dua kegiatan ini saling melengkapi dan berpadu menjadi komunikasi lisan, seperti dalam bercakap-cakap, diskusi, bertelepon, tanya jawab dan interview. Keterampilan berbicara merupakan salah satu jenis kemampuan berbahasa yang ingin dicapai dalam pengajaran bahasa modern termasuk bahasa Arab. Tujuan dari penelitian ini adalah untuk mengetahui sejauh mana kemampuan menyimak dan aktifitas berpidato, serta korelasi keduanya terhadap kemampuan berbicara bahasa Arab pada siswa kelas XI Jurusan Ilmu Pengetahuan Sosial (IPS) Madrasah Aliyah Manba'ul 'Ulum Dukupuntang-Cirebon. Jenis penelitian ini adalah penelitian ex-post-facto, sedangkan metode yang digunakan dalam penelitian ini adalah metode kuantitatif dengan rancangan deskriptif-korelasional. Adapun populasinya adalah seluruh siswa kelas XI Madrasah Aliyah Manba'ul 'ulum DukupuntangCirebon yang berjumlah 100 siswa. Sedangkan teknik pengambilan sampel menggunakan Probability Sampling berupa Cluster Random Sampling yaitu kelas XI IPS yang berjumlah 20 siswa. Pengumpulan data diperoleh melalui tes dan wawancara tidak terstruktur. Teknik analisis datanya menggunakan uji normalitas dan uji hipotesis. Adapun hasil penelitiannya adalah : (1) terdapat hubungan yang positif dan signifikan antara kemampuan menyimak dengan kemampuan berbicara siswa dengan nilai rhitung lebih besar dari rtabel $(0,769>0,4438)$ dan nilai signifikansi sebesar $0,000<0,5$ maka Ho ditolak; (2) terdapat hubungan yang positif dan signifikan antara aktifitas berpidato dengan kemampuan berbicara siswa dengan nilai rhitung lebih besar dari rtabel $(0,786>0,4438)$ dan nilai signifikansi sebesar 0,000<0,5 maka Ho ditolak; (3) terdapat hubungan yang positif dan signifikan antara kemampuan menyimak dan aktifitas berpidato dengan kemampuan berbicara siswa dengan nilai rhitung lebih besar dari rtabel $(0,822>0,4438)$ dan nilai signifikansi sebesar 0,000 yang berarti kurang dari $0,05(0,000<0,5)$ maka Ho ditolak. Artinya, ada hubungan antara kemampuan menyimak dan aktifitas berpidato dengan kemampuan berbicara. Sehingga, kemampuan menyimak dan aktifitas berpidato mempunyai peran penting dalam meningkatkan kemampuan berbicara Bahasa Arab siswa. 
Kata Kunci : Kemampuan Menyimak, Kegiatan Berpidato, Kemampuan Berbicara

ملخحص

لا يمكن فصل أنشطة الإستماع من أنشطة الكالام في الحياة اليوميّة ، ومن المستحيل أن يّستمع أحد حينما لم يتكلّم أحد، وبالعكس. وهاتان النشيطتان ودابحان في التواصل الشفهيّ، كما في لئ التكلّم والمناقشة والاتّصال بالهاتف والسؤال والجواب والمقابلة ـ مهارة الكلام هي أحد أنواع المهارات اللغوية المراد تحقيقها في تدريس اللغات الحديثة بما في ذلك اللغة العربية. أمّا اهداف من هذه الرسالة فهي لمعرفة قدرة الاستماع وأنشطة الخطابة وعلاقتهما بقدرة الكلام باللغة العربية في الصف الحادي عشر من قسم العلوم الاجتماعيّة بمدرسة منبع العلوم العالية الإسلاميّة دوكوبونتانج - شربون. ونوع البحث في هذه الرسالة هو وطريقة البحث فن هذه الرسالة هي الطريقة الكمية بإجراءات البحث الارتباط . وأمّا الزمرة في هذا البحث فهو كل طلّبَ في الصّفّ

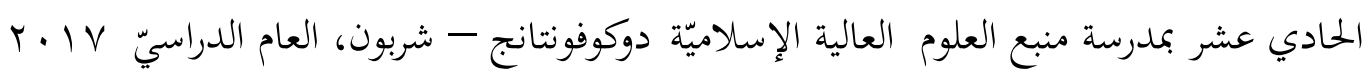
- 1 1 • ب التي تتكوّن من مائة طالبا. وأمّا المثال في هذه الرسالة فهي Probability Sampling شكل العينة العنقودية (Cluster Random Sampling). وعددهم عشرون طالبا. وطريقة جمع البيانات في هذا البحث هي الاختبار والمقابلة (غير منظّمة). وأساليب تحليل البيانات التي تستخدمها الباحثة في هذه الرسالة هي بتربة العادية وبحربة الفروض. وأمّا نتائج البحث في هذه الرسالة فهي ( 1) وجود العلاقة ايجابية ودلالية بين قدرة الاستماع وقدرة الكالام الطلاب بنتيجة

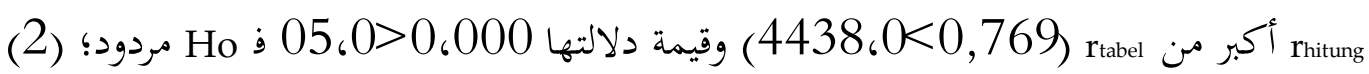
وجود العلاقة ايجابية ودلالية بين أنشطة الخطابة وقدرة الكلام الطلاب بنتيجة rhitung أكبر من rtabel

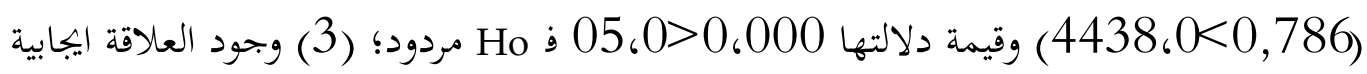
ودلالية بين قدرة الاستماع وأنشطة الخطابة وقدرة الكالام الطلاب باللغة العربية بنتيجة rhitung أكبر من م rabel (

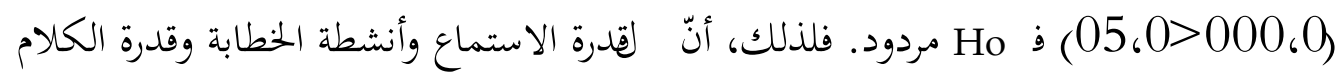
باللغة العربية علاقة بينة . وبالتالي، فإنّ مهارة الاستماع وأنشطة الخطابة لهما دور مهمّ في تحسين مهارة الكالام الطلاب. 


\section{الكلمات الئيسية: قدرة الاستماع، أنشطة الخطابة، قدرة الكلام}

\section{Pendahuluan}

Keterampilan menyimak dan berbicara mempunyai hubungan yang sangat erat. Sebab, seseorang pembicara pasti memerlukan orang yang akan mendengarkan pembicaraannya (penyimak). Meningkatkan keterampilan menyimak berarti membantu meningkatkan kualitas berbicara seseorang. Apabila si penyimak dapat memahami maksud si pembicara dengan baik, maka penyimak tentunya dapat memberikan respon yang lebih tepat. Respon ini dapat berupa jawaban, pengungkapan gagasan, atau bisa juga berupa pertanyaan pada si pembicara.

Maharatu al Kalam (keterampilan berbicara) merupakan komponen yang sangat penting dari empat komponen keterampilan berbahasa Arab dan sebagai bukti keberhasilan dari komponenkomponen dasar lainnya. Dalam komponen ini, seseorang dituntut untuk mengungkapkan sesuatu secara spontan, sehingga dituntut pembiasaan dan penguasaan kosa kata yang memadai ${ }^{1}$. Dinyatakan oleh Farris $^{2}$ bahwa pembelajaran keterampilan berbicara penting dikuasai siswa agar mampu mengembangkan kemampuan berpikir, membaca, menulis, dan menyimak. Sebuah komunikasi lisan tidak akan terjadi jika antara proses berbicara dan menyimak tidak berlangsung sekaligus, atau tidak saling melengkapi. Tarigan ${ }^{3}$ berpendapat bahwa berbicara adalah kemampuan mengucapkan bunyi-bunyi artikulasi atau kata-kata untuk mengekspresikan, menyatakan, menyampaikan pikiran, gagasan, dan perasaan. Oleh sebab itu, dengan menggunakan bahasa seseorang akan lancar mengorganisasikan ide-ide yang akan dikemukakan dengan baik melalui bicara. Salah satu contoh keterampilan berbicara adalah berpidato. Berpidato merupakan salah satu wujud kegiatan berbahasa lisan. Dengan demikian, berpidato memerlukan dan mementingkan ekspresi gagasan penalaran dengan menggunakan bahasa lisan yang

1 Lina Marlina, Signifikansi Metode Langsung Dalam Pengajaran Maharat alKalam, dalam El-Ibtikar: Jurnal Pendidikan Bahasa Arab, Vol. 04, no. 1, 2015. Hal. 137.

2 Supriyadi, Dkk, Pendidikan Bahasa Indonesia 2. (Jakarta: Depdikbud, 2005). Hal. 179.

3 Henry Guntur Tarigan, Berbicara Sebagai Suatu Keterampilan Berbahasa. (Bandung: Angkasa, 2013). Hal. 16. 
didukung oleh aspek non-bahasa, seperti ekspresi wajah, kontak pandang, dan intonasi suara.

Salah satu institusi yang ada dalam masyarakat yang mempunyai peran sangat penting dalam rangka meningkatkan kualitas Sumber Daya Manusia (SDM) adalah Pondok Pesantren, salah satunya adalah Pondok Pesantren Manba'ul 'Ulum Dukupuntang Cirebon. Kegiatan yang ada di ruang lingkup Pondok Pesantren Manba'ul ‘Ulum Dukupuntang Cirebon di antaranya adalah kegiatan muhadatsah dan kegiatan khitobah. khitobah tersebut dilakukan melainkan sebagai salah satu kegiatan untuk memajukan misi dakwah dalam Pesantren yang ditekankan kepada setiap santrinya guna sebagai pendongkrak kepercayaan diri setiap santri untuk mengasah kemampuan berpidatonya didepan khalayak umum.

\section{Metode Penelitian}

Lokasi penelitian dilakukan di Madrasah Aliyah Manba'ul ‘Ulum Dukupuntang-Cirebon, tepatnya di Jl. Nyi Ageng Serang Sindangmekar Dukupuntang-Cirebon, 45652 Jawa Barat. Waktu penelitian tersebut dilaksanakan pada tanggal 31 Agustus - 30 November 2018.

Penelitian ini merupakan penelitian kuantitatif dengan jenis penelitian ex-post-facto, karena penelitian ini dilakukan untuk meneliti peristiwa yang telah terjadi dan kemudian menuntut ke belakang untuk mengetahui hal yang dapat menimbulkan kejadian tersebut. Sedangkan pendekatan yang digunakan dalam penelitian ini adalah pendekatan kuantitatif dengan rancangan deskriptif-korelasional ${ }^{4}$. Sumber data pada penelitian ini adalah Guru Bahasa Arab kelas XI, Siswa kelas XI, dan buku-buku ilmiah, internet, serta referensi lain yang berhubungan dengan penulisan skripsi ini. Jumlah populasinya adalah seluruh siswa kelas XI Madrasah Aliyah Manba'ul ‘Ulum Dukupuntang Cirebon Tahun Pelajaran 2017/2018 sebanyak 100 siswa. Populasi merupakan keseluruhan subjek penelitian. ${ }^{5}$ Sedangkan teknik sampel yang digunakan pada penelitian ini adalah Probability Sampling berupa Cluster Random Sampling, karena sampelnya telah ditentukan yaitu kelas XI IPS

${ }^{4}$ Sugiyono, Metode Penelitian Pendidikan; Pendekatan Kuantitatif, Kualitatif dan RED. (Bandung: Alfabeta, 2007). Hal. 15.

${ }^{5}$ Suharsimi Arikunto, Prosedur Penelitian Suatu Pendekatan Praktik. (Jakarta: Rineka Cipta, 2010). Hal. 110. 
(2) Madrasah Aliyah Manba'ul 'Ulum Dukupuntang Cirebon yang berjumlah 20 siswa. Sampel merupakan sebagian dari populasi yang diambil dengan cara tertentu pada populasi yang hendak diteliti dan digeneralisasikan hasilnya untuk penelitian tersebut. ${ }^{6}$

Peneliti melakukan teknik pengumpulan data dengan berupa tes lisan dan wawancara tidak terstruktur. Kemudian, teknik analisis data yang digunakan dalam penelitian ini berupa uji normalitas dan uji hipotesis statistik.

\section{Kemampuan Menyimak (al Qudrah al Istima')}

Kemampuan adalah suatu kesanggupan, kecakapan dan kekuatan untuk melakukan sesuatu ${ }^{7}$. Menurut $A n i s^{8}$ dalam al-Mu'jam alWasith, bahwa mendengar secara etimologis adalah mengekspresikan apa yang didengar secara baik. Sedangkan mendengar secara terminologis adalah kemampuan seseorang untuk mengidentifikasi materi yang diperdengarkan dengan penuh perhatian, pemahaman, apresiasi, serta interpretasi untuk memperoleh informasi, menangkap isi atau pesan, serta memahami makna yang telah disampaikan pembicara melalui bahasa lisan. ${ }^{9} \quad$ Sedangkan yang dimaksud kemampuan menyimak pada penelitian ini adalah memahami makna (isi) pidato yang berlangsung ketika kegiatan khitobah di Pondok Pesantren Manba'ul ‘Ulum Dukupuntang Cirebon.

Adapun tujuan menyimak menurut Hasan Saefulloh ${ }^{10}$ adalah sebagai berikut:

a. Tujuan menyimak untuk tingkat pemula:

a) Mengetahui suara Arab dan membedakannya secara signifikan.

b) Membedakan antara suara yang berdekatan dalam pengucapan dan suara yang serupa.

${ }^{6}$ Suharsimi Arikunto, Prosedur Penelitian Suatu Pendekatan Praktik. (Jakarta: Rineka Cipta, 2010). Hal. 110.

${ }^{7}$ Hasan Alwi, Kamus Besar Bahasa Indonesia. (Jakarta: Balai Pustaka, 2007). Hal. 708.

8 Ibrahim Anis, al Mu'jam al Wasith. (Kairo: 1972). Hal. 449.

${ }^{9}$ Rodliyah Zaenuddin, Penggunaan Media Sederhana Daalam Pembelajaran Bahasa Arab. (Cirebon: IAIN Syekh Nurjati Cirebon, 2013). Hal. 114-115.

10 Hasan Saefuloh, Teknik Pembelajaran Keterampilan Bahasa Arab. (Cirebon: Nurjati Press, 2012). Hal. 2. 
c) Mengetahui harokat panjang pendek dan perbedaan di antara keduanya.

b. Tujuan menyimak untuk tingkat menengah :

a) Memahami apa yang disampaikan dalam bahasa Arab modern dan ritme alami dalam batas-batas kosakata yang dipelajari.

b) Memahami dan membedakan antara simbol tertulis dan fonetik.

c) Membedakan antara fakta dan opini melalui konteks percakapan normal.

c. Tujuan menyimak untuk tingkat tinggi/atas :

a) Siswa dapat menggambarkan apa yang mereka dengar dari materi.

b) Siswa dapat menarik kesimpulan dari apa yang mereka dengar dari awal.

c) Siswa dapat menjawab apa yang mereka dengar dari materi.

Ada 3 hal yang dapat mempengaruhi keberhasilan proses Menyimak (Istima'), yaitu: ${ }^{11}$

a. Materi yang diperdengarkan harus sesuai dengan latar belakang pengetahuan, pengalaman dan minat mendengar.

b. Faktor fisik, psikologis dan kemampuan kebahasaan pendengar.

c. Suasana tempat proses istima'.

Selain itu, faktor menyimak yang baik memerlukan suatu kondisi yang mendukung, di antara faktor-faktor menyimak yang baik meliputi:

a. Alat pendengaran yang baik.

b. Situasi dan lingkungan yang baik.

c. Konsentrasi yang baik.

d. Pengenalan tujuan pembicaraan.

e. Kemampuan menangkap pokok-pokok pikiran.

f. Kesanggupan menarik kesimpulan dengan tepat.

Kemampuan menyimak Bahasa Arab pada siswa kelas XI IPS Madrasah Aliyah Manba'ul ‘Ulum Dukupuntang Cirebon

\section{Statistics}

kemampuan menyimak

\begin{tabular}{|ll|r|}
\hline $\mathrm{N}$ & Valid & 20 \\
& Missing & 0
\end{tabular}

11 Suhendar \& Pien Supinah, Bahasa Indonesia: Pengajaran dan Ujian Keterampilan Menyimak dan Keterampilan Berbicara. (Bandung: Pionar Jaya, 1992). Hal. 50. 


\begin{tabular}{|l|r|} 
Mean & 76.1800 \\
Median & 74.9000 \\
Mode & $68.60^{\mathrm{a}}$ \\
Std. Deviation & 4.23775 \\
Variance & 17.959 \\
Minimum & 68.60 \\
Maximum & 83.10 \\
Sum & 1523.60 \\
\hline
\end{tabular}

a. Multiple modes exist. The smallest value is shown

Tabel di atas menunjukkan jumlah siswa sebanyak 20 siswa. Missing 0 menunjukkan bahwa data yang hilang adalah nol, dengan demikian tidak ada data yang belum diproses.

Nilai Mean atau rata-rata kemampuan menyimak sebesar 76,18, Median diperoleh dengan cara mengurutkan semua data yang sama besar dibagi dua. Median atau titik tengah pada tabel di atas sebesar 74,9, menunjukkan bahwa 50\% sampel rata-rata siswa 74,9 ke atas, dan 50\% sampel lain rata-rata di bawah 74,9, Mode didapat 68,6. Besarnya standar deviasi adalah 4,23775 dan varian sebesar 17,959 sementara nilai minimal dan maksimal masing-masing sebesar 68,8 dan 83,10 dengan jumlah total 1523.60 .

\section{Kegiatan Berpidato (Khitobah)}

Pidato adalah sebuah kegiatan berbicara di depan umum atau bisa dikatakan sebagai public speaking ${ }^{12}$. Menurut Rosalina ${ }^{13}$, pidato adalah kegiatan seseorang yang dilakukan di hadapan orang banyak dengan mengandalkan kemampuan bahasa sebagai alatnya. Oleh sebab itu, berpidato merupakan kegiatan berbahasa yang berstandar keterampilan, yakni keterampilan berbicara. Dengan demikian, pengertian berpidato dapat merujuk pada keterampilan berbicara. Tujuan utama dari aktivitas berpidato yakni untuk berkomunikasi. Dengan demikian, berpidato yang baik adalah mengkomunikasikan pesan secara baik kepada pendengar. ${ }^{14}$

12 Putri Pandan Wangi, Bukan Pidato Biasa. (Klaten: One Books, 2010). Hal. 11.

13 Susi Rosalina, Contoh MC dan Pidato Praktis Lengkap Dengan Seminar. (Surabaya: Amanan, 1991). Hal. 23.

${ }^{14}$ Maidar Arsjad \& Mukti US, Pembinaan Kemampuan Berbicara Bahasa Indonesia. (Jakarta: Erlangga, 1988). Hal. 24. 
Dalam penelitian ini, pidato adalah salah satu kegiatan ekstra, terutama di pondok pesantren Manba'ul 'Ulum Dukupuntang-Cirebon yang menggunakan bahasa Arab yang diawasi langsung oleh para pembimbing, serta dilakukan setiap satu minggu sekali yaitu setiap malam ahad, dan pidato adalah salah satu kegiatan yang menghasilkan keterampilan berbicara di kalangan para siswa.

Berdasarkan sifat dan isi pidato, Pidato itu dibagi menjadi enam jenis ${ }^{15}$ antara lain:

a. Pidato Pembukaan

Yaitu jenis pidato singkat yang dibawakan oleh pembawa acara (Master of Ceremony).

b. Pidato pengarahan

Yaitu jenis pidato untuk mengarahkan pada suatu pertemuan, seperti:

Pengarahan tentang pentingnya menjaga kebersihan di lingkungan sekolah.

c. Pidato sambutan

Yaitu jenis pidato yang disampaikan pada suatu acara kegiatan atau peristiwa tertentu yang dapat dilakukan oleh beberapa orang dengan waktu yang terbatas secara bergantian, seperti: Sambutan dari ketua DKM masjid sebagai ketua panitia penyelenggara peringatan Maulid Nabi Muhammad SAW.

d. Pidato peresmian

Yaitu jenis pidato yang dilakukan oleh seseorang yang berpengaruh ketika akan meresmikan sesuatu. seperti: Peresmian terhadap pembangunan masjid yang diresmikan secara simbolis oleh ketua DKM masjid dan Kepala Desa.

e. Pidato laporan

Yaitu jenis pidato yang isinya adalah melaporkan sesuatu tugas atau kegiatan. seperti: Laporan ketua panitia Qurban di Hari Raya 'Idul Adha.

f. Pidato pertanggungjawaban

Yaitu jenis pidato yang berisi suatu laporan pertanggungjawaban terhadap suatu kegiatan tertentu.

Selain itu, pada umumnya kegiatan berpidato memiliki tujuan sebagai berikut: ${ }^{16}$

15 Asep Yudha Wijaya \& Sudarmawati, Berbahasa dan Bersastra Indonesia. (Surakarta: Pusat Perbukuan Departemen Pendidikan Nasional, 2008). Hal. 180. 
a. Bersifat informatif, yaitu memberikan sebuah pemahaman maupun informasi baru terhadap orang lain.

b. Bersifat persuasif, yaitu mempengaruhi pendapat atau pendirian pendengar.

c. Bersifat rekreatif, yaitu menyenangkan pihak audiens dengan pidato yang dibawakan sehingga tercapai kepuasan dan kesenangan terhadap apa yang disampaikan.

d. Bersifat argumentatif, yaitu meyakinkan para pendengar.

Terdapat beberapa hal yang perlu diperhatikan saat berbicara di depan umu. Ada beberapa faktor yang dapat menunjang keefektifan berpidato. Faktor-faktor itu adalah faktor kabahasaan dan faktor nonkebahasaan, antara lain sebagai berikut: ${ }^{17}$

a. Faktor Kebahasaan

Faktor-faktor kebahasaan sebagai penunjang keefektifan berpidato meliputi ketepatan ucapan, penempatan tekanan, nada, sendi dan durasi yang sesuai, pilihan kata (diksi), dan ketepatan sasaran pembicaraan.

b. Faktor Non-kebahasaan

Dalam pembicaraan formal, faktor non-kebahasaan ini sangat mempengaruhi keefektifan berbicara. Di antara faktor-faktor nonkebahasaan antara lain, (a) Sikap yang wajar, tenang, dan tidak kaku; (b) Pandangan pada lawan bicara; (c) Kesediaan menghargai pendapat orang lain; (d) Gerak-gerik dan mimik yang tepat; (e) Kenyaringan suara; (f) Kelancaran; (g) Relevansi (penalaran); dan (h) Penguasaan topik. c. Kriteria Pidato yang Baik

Seseorang yang berpidato dengan baik akan meyakinkan pendengarnya untuk menerima dan mematuhi pikiran, informasi, gagasan atau pesan yang disampaikannya. Beberapa faktor yang harus diperhatikan agar dapat berpidato dengan baik adalah sebagai berikut:

a) Harus mempunyai tekad dan keyakinan.

b) Harus memiliki pengetahuan yang luas.

c) Harus mempunyai perbendaharaan kata yang cukup.

d) Harus mempunyai kebiasaan atau latihan yang intensif.

16 Indriyana Rahmawati, https://portal-ilmu.com/pengertian-tujuan-metodepidato/, 2006 (diakses pada tanggal 14 November 2018).

17 Indriyana Rahmawati, https://portal-ilmu.com/pengertian-tujuan-metodepidato/, 2006 (diakses pada tanggal 14 November 2018). Hal. 17-22. 
Adapun langkah-langkah yang bisa ditempuh untuk menyusun sebuah pidato adalah sebagai berikut: ${ }^{18}$

a) Menentukan topik pembicaraan.

b) Menetapkan tujuan.

c) Menyusun kerangka pidato.

d) Menyusun teks pidato.

e) Menyunting teks pidato.

Berikut ini adalah unsur-unsur utama yang harus disebutkan dalam bepidato: ${ }^{19}$

a) Pendahuluan atau Pengantar.

b) Isi.

c) Hasil atau kesimpulan.

Aktifitas berpidato Bahasa Arab pada siswa kelas XI IPS Madrasah Aliyah Manba'ul ‘Ulum Dukupuntang Cirebon

Statistics

\begin{tabular}{|c|c|c|}
\hline \multirow{2}{*}{$\mathrm{N}$} & Valid & 20 \\
\hline & Missing & 0 \\
\hline $\mathrm{Me}$ & & 76.6975 \\
\hline \multicolumn{2}{|c|}{ Median } & 76.0500 \\
\hline \multicolumn{2}{|c|}{ Mode } & 80.00 \\
\hline \multicolumn{2}{|c|}{ Std. Deviation } & 2.88519 \\
\hline \multicolumn{2}{|c|}{ Variance } & 8.324 \\
\hline \multicolumn{2}{|c|}{ Minimum } & 72.70 \\
\hline \multicolumn{2}{|c|}{ Maximum } & 82.20 \\
\hline \multicolumn{2}{|c|}{ Sum } & 1533.95 \\
\hline
\end{tabular}

Tabel di atas menunjukkan jumlah siswa sebanyak 20 siswa. Missing 0 menunjukkan bahwa data yang hilang adalah nol, dengan demikian tidak ada data yang belum diproses.

Nilai Mean atau rata-rata aktifitas berpidato sebesar 76,70, Median diperoleh dengan cara mengurutkan semua data yang sama besar dibagi dua. Median atau titik tengah pada tabel di atas sebesar

${ }^{18}$ Auriga Maulana Khasan, http://akses-ilmu.blogspot.com/2012/05/definisipidato-jenis-tujuan-metode.html, 2012 (diakses pada tanggal 14 November 2018).

${ }^{19}$ Ahmad Fuad Mahmud 'Ilyan, al Maharat al Lughawiyyah: Maa hiyatuha wa Tharaiq Tadrisiha. (ar-Riyadh: Daar al Muslim li Nasyr wa Tauzi', tt). Hal. 185-186. 
76,05, menunjukkan bahwa 50\% sampel rata-rata siswa 76,05 ke atas, dan $50 \%$ sampel lain rata-rata di bawah 76,05, Mode didapat 80 . Besarnya standar deviasi adalah 2,88519 dan varian sebesar 8,324 sementara nilai minimal dan maksimal masing-masing sebesar 72,70 dan 82,20 dengan jumlah total 1533,95.

\section{Kemampuan Berbicara (al Qudrah al Kalam)}

Berbicara adalah ungkapan yang disampaikan pembicara sebagai ekspresi jiwanya, baik berupa gagasan, perasaan, atau pemikiran yang memberikan pengertian, pemahaman, daninformasi bagi pendengarnya ${ }^{20}$. Menurut Effendi ${ }^{21}$, kegiatan berbicara di dalam kelas mempunyai aspek komunikasi dua arah, yakni antara pembicara dengan pendengarnya secara timbal balik. Dengan demikian, latihan berbicara harus terlebih dahulu didasari oleh (1) Kemampuan mendengar, (2) Kemampuan mengucapkan, (3) Penguasaan relatif kosa kata dan ungkapan yang memungkinkan siswa dapat mengkomunikasikan maksud, gagasan atau fikirannya.

Tujuan keterampilamn berbicara dapat diklasifikasikan menjadi tiga bagian, yaitu sebgaai berikut: ${ }^{22}$

a. Tujuan keterampilan berbicara untuk tingkat pemula:

a) Mengucapkan bunyi huruf sesuai dengan makhrajnya.

b) Merangkai kata dan kalimat dasar secara logis dan sistematis.

c) Melafalkan contoh dilaog sederhana yang disiapkan oleh guru.

b. Tujuan keterampilan berbicara untuk tingkat menengah:

a) Menggunakan kosa kata yang tepat dan menguasai idiom dan peristilahan.

b) Melakukan percakapan sederhana dengan bahasa yang baik dan benar.

c) Menyampaikan cerita sederhana dengan lancar.

c. Tujuan keterampilan berbicara untuk tingkat atas/lanjut:

a) Melakukan wawancara/interview.

b) Memberikan komentar pada suatu berita atau peristiwa.

${ }^{20}$ Ahmad Fuad Mahmud 'Ilyan, al Maharat al Lughawiyyah: Maa hiyatuha wa Tharaiq Tadrisiha. (ar-Riyadh: Daar al Muslim li Nasyr wa Tauzi', tt). Hal. 86.

${ }^{21}$ Ahmad Fuad Effendi, Metodologi Pengajaran Bahasa Arab. (Malang: Misykat, 2009). Hal. 139.

${ }^{22}$ Fuad Effendi, Metodologi Pengajaran Bahasa Arab. (Malang: Misykat, 2009). Hal. 4-5. 
c) Menyampaikan ceramah dengan baik dan lancar.

Ada beberapa faktor yang perlu diperhatikan seseorang untuk dapat menjadi pembicara yang baik. Faktor-faktor tersebut adalah faktor kebahasaan dan non-kebahasaan. Menurut Efendy, ${ }^{23}$ unsur kebahasaan dan non-kebahasaan tersebut sebagai berikut:

Aspek Kebahasaan, meliputi: (1) Pengucapan (makhraj), Kejelasan suara (shifatul huruf), (3) Penempatan tekanan (mad, syiddah), (4) Nada dan irama, (5) Pilihan kata, (6) Pilihan ungkapan, (7) Susunan kalimat. Sedangkan aspek Non-kebahasaan, meliputi: (1) Kelancaran, (2) Penguasaan Topik, (3) Keterampilan, (4) Penalaran, (5) keberanian, (6) Kelincahan, (7) Ketertiban, (8) Kerajinan, (9) Kerjasama.

Kemampuan berbicara Bahasa Arab pada siswa kelas XI IPS Madrasah Aliyah Manba’ul ‘Ulum Dukupuntang Cirebon

\section{Statistics}

kemampuan berbicara

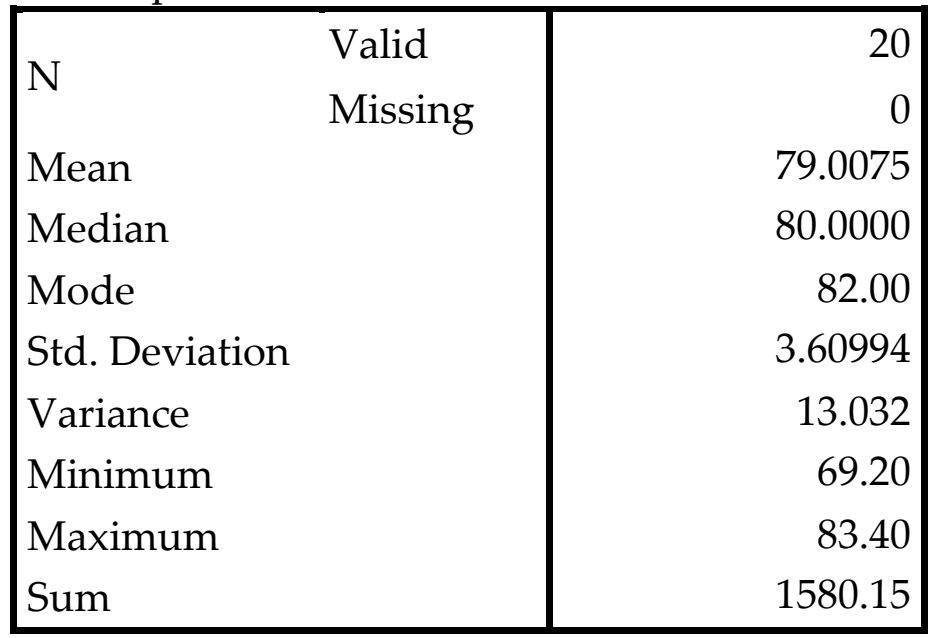

Tabel di atas menunjukkan jumlah siswa sebanyak 20 siswa. Missing 0 menunjukkan bahwa data yang hilang adalah nol, dengan demikian tidak ada data yang belum diproses.

Nilai Mean atau rata-rata kemampuan berbicara sebesar 79,01, Median diperoleh dengan cara mengurutkan semua data yang sama besar dibagi dua. Median atau titik tengah pada tabel di atas sebesar 80, menunjukkan bahwa 50\% sampel rata-rata siswa 80 ke atas, dan 50\% sampel lain rata-rata di bawah 80, Mode didapat 82. Besarnya standar Hal. 153.

23 Fuad Effendi, Metodologi Pengajaran Bahasa Arab. (Malang: Misykat, 2009). 
deviasi adalah 2,60994 dan varian sebesar 13,032 sementara nilai minimal dan maksimal masing-masing sebesar 69,20 dan 83,40 dengan jumlah total 1580,15.

\section{Deskripsi singkat Madrasah Aliyah Manba'ul 'Ulum Dukupuntang Cirebon}

Madrasah Aliyah Manba'ul 'Ulum Dukupuntang-Cirebon merupakan suatu lembaga pendidikan yang berada di bawah Departemen Pendidikan Agama Islam yang berlokasi di Jl. Nyi Ageng Serang Desa Sindangmekar Kecamatan Dukupuntang Kabupaten Cirebon (45652) Provinsi Jawa Barat. Di samping sekolah tersebut memiliki letak yang sangat strategis dan juga banyak mendapatkan sorotan dari masyarakat sekitar, baik dari daerah Cirebon maupun sekitarnya.

Madrasah Aliyah Manba'ul 'Ulum Dukupuntang-Cirebon merupakan suatu lembaga pendidikan yang dikelola di bawah naungan sebuah Yayasan yang bernama Yayasan Pondok Pesantren Manba'ul 'Ulum Dukupuntang-Cirebon, yang dipimpin oleh KH. Mahfudz Hudlori, M. HI. Yayasan tersebut dalamnya terdiri dari lembaga SD/MI, MTs, dan MA. Pada mulanya, Yayasan tersebut berawal dari sebuah tempat pengajian Al-Qur'an yang sangat sederhana, yaitu mengajarkan Al-Qur'an untuk santri kalong (santri yang tidak menetap atau pulangpergi) sebelum tahun 1970-an yang dirintis oleh KH. Ghojali. Kemudian, putra dari KH. Ghojali, yaitu KH. Mahfudz Suja'i melanjutkan pengajaran Al-Qur'an dengan santri-santri kalong dan dilengkapi dengan mendirikan Madrasah Diniyah Awaliyah (MDA) dan mendirikan SMP Sindangjawa pada tahun 1983.

Setelah itu, kira-kira pada tahun 1995-an, atas intruksi yayasan agar nama lembaga disesuaikan dengan nama yayasannya menjadi Pondok Pesantren Manba'ul 'Ulum Cirebon. Pada tahun 2000, Pondok Pesantren Manba'ul 'Ulum Cirebon resmi membuka program terpadu TMI (Tarbiyatul Mu'allimien Al-Islamiyah), termasuk Madrasah Aliyah Manba'ul 'Ulum Dukupuntang-Cirebon. Madrasah Aliyah tersebut beroperasi pada tahun 2004 di bawah pimpinan kepala sekolah yang bernama H. As'ad Samawat, S. Ag.

\section{Pembelajaran Bahasa Arab di Madrasah Aliyah Manba'ul 'Ulum Dukupuntang Cirebon}


Madrasah Aliyah Manba'ul 'Ulum Dukupuntang-Cirebon merupakan salah satu sekolah di Cirebon yang menerapkan sistem pesantren. Waktu belajar siswa dibagi menjadi 2 bagian, pertama untuk sekolah formal dan kedua untuk sekolah non formal. Pada waktu pagi sampai menjelang siang, para siswa berangkat sekolah untuk mengikuti kegiatan belajar formal (SD/MI, MTs, dan MA) sama halnya seperti sekolah umum lainnya. Akan tetapi, setelah itu siswa harus mengikuti kegiatan belajar non formal di Pondok Pesantren, artinya belajar Diniyyah untuk mata pelajaran di dalam Pondok Pesantren, meliputi pembelajaran muhadatsah, muthala'ah, nahwu dan shorof.

Madrasah Aliyah Manba'ul 'Ulum Dukupuntang-Cirebon memiliki kurikulum yang sama dengan sekolah formal lainnya. Tenaga pengajar pelajaran bahasa Arab di sekolah tersebut merupakan tenaga pengajar yang berkualitas, ada beberapa di antaranya yang lulusan dari Mesir. Di samping itu, pada mata pelajaran bahasa Arab guru menerapkan berbagai metode dan media yang bervariasi guna melatih peserta didik agar memperoleh kemahiran berbahasa, di antaranya kemahiran menyimak, berbicara, membaca dan menulis, serta dapat melatih peserta didik dalam kehidupan sehari-hari menggunakan bahasa Arab. Salah satunya, bahwasannya mayoritas siswa telah mampu memahami kata-kata dan kalimat-kalimat lisan bahasa Arab dalam percakapan sehari-hari.

Korelasi kemampuan menyimak dan aktifitas berpidato terhadap kemampuan berbicara Bahasa Arab

Uji Normalitas

Uji normalitas dilakukan untuk mengetahui apakah data berdistribusi normal atau tidak. Pada pembahasan ini, uji normalitas dilakukan dengan menggunakan uji Kolmogorov-Smirnova.

Dasar pengambilan keputusan dalam pengujian normalitas dengan menggunakan uji Kolmogorov-Smirnov a yaitu :

a. Nilai sig. atau signifikansi atau nilai probabilitas $>0,05$, maka data berdistribusi normal.

b. Nilai sig. atau signifikansi atau nilai probabilitas $<0,05$, maka data berdistribusi data tidak normal.

One-Sample Kolmogorov-Smirnov Test

\begin{tabular}{|c|c|c|c|}
\hline & $\begin{array}{c}\text { kemampuan } \\
\text { menyimak }\end{array}$ & $\begin{array}{c}\text { aktifitas } \\
\text { berpidato }\end{array}$ & $\begin{array}{c}\text { kemampuan } \\
\text { berbicara }\end{array}$ \\
\hline
\end{tabular}




\begin{tabular}{|ll|r|r|r|}
\hline $\mathrm{N}$ & & 20 & 20 & 20 \\
& Mean & 76.1800 & 76.6975 & 79.0075 \\
Normal Parameters & Std. & 4.23775 & 2.88519 & 3.60994 \\
& Deviation & & & \\
Most Extreme & Absolute & .166 & .141 & .176 \\
Differences & Positive & .160 & .141 & .154 \\
& Negative & -.166 & -.124 & -.176 \\
Kolmogorov-Smirnov Z & & .744 & .631 & .787 \\
Asymp. Sig. (2-tailed) & & .638 & .821 & .565 \\
\hline
\end{tabular}

a. Test distribution is Normal.

b. Calculated from data.

Hasil uji normalitas pada tabel test of normality di atas data kemampuan menyimak menunjukkan nilai signifikan pada uji kolmogorov sebesar 0,638. Karena tersebut nilai signifikan berada di atas 0,05. Maka data kemampuan menyimak berdistribusi normal.

Uji normalitas aktifitas berpidato menunjukkan nilai signifikan pada uji kolmogorov sebesar 0,821 . Karena nilai signifikan berada di atas 0,05. Maka data aktifitas berpidato berdistribusi normal.

Uji normalitas kemampuan berbicara menunjukkan nilai signifikan pada uji kolmogorov sebesar 0,656. Karena nilai signifikan berada di atas 0,05 . Maka data kemampuan berbicara berdistribusi normal.

\section{Uji Korelasi antara kemampuan menyimak dengan kemampuan berbicara}

\begin{tabular}{|ll|r|r|}
\multicolumn{2}{|c|}{ Correlations } \\
\hline & Pearson Correlation & $\begin{array}{c}\text { kemampuan } \\
\text { menyimak }\end{array}$ & $\begin{array}{c}\text { kemampuan } \\
\text { berbicara }\end{array}$ \\
\hline kemampuan & Sig. (2-tailed) & 1 & $.769^{* *}$ \\
menyimak & $\mathrm{N}$ & 20 & .000 \\
& Pearson Correlation & $.769^{* *}$ & 20 \\
& Sig. (2-tailed) & .000 & 1 \\
kemampuan berbicara & 20 & 20 \\
& $\mathrm{~N}$ & & \\
&
\end{tabular}

**. Correlation is significant at the 0.01 level (2-tailed).

Hasil output SPSS di atas nilai pearson correlation antara kemampuan menyimak dengan kemampuan berbicara sebesar 0,769. Nilai korelasi ini berada di antara 0,600 sampai dengan 0,799 maka hubungannya adalah kuat. Artinya hubungan kemampuan menyimak dengan kemampuan berbicara adalah kuat. 


\section{Uji korelasi aktifitas berpidato dengan kemampuan berbicara Bahasa} Arab

\begin{tabular}{|ll|r|r|}
\hline \multicolumn{2}{|c|}{ Correlations } & \multicolumn{1}{c|}{$\begin{array}{c}\text { aktifitas } \\
\text { berpidato }\end{array}$} & $\begin{array}{c}\text { kemampuan } \\
\text { berbicara }\end{array}$ \\
\hline & Pearson Correlation & 1 & $.786^{* * *}$ \\
aktifitas berpidato & Sig. (2-tailed) & .000 \\
& $\mathrm{~N}$ & 20 & 20 \\
& Pearson Correlation & $.786^{* *}$ & 1 \\
kemampuan berbicara & Sig. (2-tailed) & .000 & \\
& $\mathrm{~N}$ & 20 & 20 \\
\hline
\end{tabular}

**. Correlation is significant at the 0.01 level (2-tailed).

Hasil output SPSS di atas nilai pearson correlation antara aktifitas berpidato dengan kemampuan berbicara sebesar 0,786. Nilai korelasi ini berada di antara 0,600 sampai dengan 0,799 maka hubungannya adalah kuat. Artinya hubungan aktifitas berpidato dengan kemampuan berbicara adalah kuat.

\section{Hubungan kemampuan menyimak dan aktifitas berpidato dengan kemampuan berbicara}

Model Summary

\begin{tabular}{|l|r|r|r|c|}
\hline Model & \multicolumn{1}{|c|}{$\mathrm{R}$} & R Square & \multicolumn{1}{c|}{$\begin{array}{c}\text { Adjusted } \mathrm{R} \\
\text { Square }\end{array}$} & $\begin{array}{c}\text { Std. Error of the } \\
\text { Estimate }\end{array}$ \\
\hline 1 & $.822^{\mathrm{a}}$ & .675 & .637 & 2.17540 \\
\hline
\end{tabular}

a. Predictors: (Constant), aktifitas berpidato, kemampuan menyimak

Hasil output SPSS di atas nilai pearson correlation antara kemampuan menyimak dan aktifitas berpidato dengan kemampuan berbicara sebesar 0,822 . Nilai korelasi ini berada di antara 0,800 sampai dengan 0,999 maka hubungannya adalah sangat kuat. Artinya Hubungan kemampuan menyimak dan aktifitas berpidato dengan kemampuan berbicara adalah sangat kuat.

\section{Uji Hipotesis}

Setelah megetahui besarnya koefisien korelasi, maka perlu dilakukan pengujian hipotesis untuk megetahui apakah terdapat hubungan atau tidak. Uji hipotesis dapat dinyatakan dengan membandingkan nilai signifikan yaitu:

Jika nilai signifikan $>0,05$ dan rhitung $<$ rtabel, maka $\mathrm{H}_{0}$ diterima

Jika nilai signifikan $<0,05$ dan rhitung $>\mathrm{r}_{\text {tabel, }}$ maka $\mathrm{H}_{0}$ ditolak 
Jika tabel dicari dengan $\alpha=0,05$ dan (df) n-2 atau $20-2=18$, jadi $\mathrm{r}_{\text {tabel }}=0.4438$

a. Hipotesis pertama (hubungan kemampuan menyimak dengan kemampuan berbicara)

Berdasarkan hasil uji korelasi nilai signifikan sebesar 0,000 dan rhitung sebesar 0,769. Karena nilai signifikan lebih kecil dari 0,05 dan rhitung $(0,769)$ lebih besar dari rabel $(0,4438)$ maka Ho ditolak, artinya bahwa ada hubungan kemampuan menyimak dengan kemampuan berbicara.

\section{b. Hipotesis kedua (hubungan aktifitas berpidato dengan kemampuan berbicara)}

Berdasarkan hasil uji korelasi nilai signifikan sebesar 0,000 dan rhitung sebesar 0,786. Karena nilai signifikan lebih kecil dari 0,05 dan rhitung $(0,786)$ lebih besar dari rabel $(0,4438)$ maka Ho ditolak, artinya bahwa ada hubungan aktifitas berpidato dengan kemampuan berbicara

c. Hipotesis ketiga (hubungan kemampuan menyimak dan aktifitas berpidato dengan kemampuan berbicara)

Berdasarkan hasil uji korelasi nilai signifikan sebesar 0,000 dan rhitung sebesar 0,822. Karena nilai signifikan lebih kecil dari 0,05 dan rhitung $(0,822)$ lebih besar dari rabel $(0,4438)$ maka Ho ditolak, artinya bahwa ada hubungan kemampuan menyimak dan aktifitas berpidato dengan kemampuan berbicara.

\section{Kesimpulan}

Berdasarkan penelitian yang telah dilakukan, didapati hasil analisis dan pembahasan tentang "Korelasi kemampuan menyimak dan aktifitas berpidato terhadap kemampuan berbicara bahasa Arab bagi siswa kelas XI Madrasah Aliyah Manba'ul 'Ulum DukupuntangCirebon", maka kesimpulan yang dapat dikemukakan adalah sebagai berikut: (1) terdapat hubungan yang positif dan signifikan antara kemampuan menyimak dengan kemampuan berbicara siswa kelas XI Madrasah Aliyah Manba'ul 'Ulum Dukupuntang-Cirebon dengan nilai rhitung lebih besar dari rtabel, yaitu 0,769>0,4438 dengan taraf signifikansi $5 \%$, maka terdapat hubungan antara kemampuan menyimak dengan kemampuan berbicara; (2) terdapat hubungan yang positif dan signifikan antara aktifitas berpidato dengan kemampuan berbicara siswa kelas XI Madrasah Aliyah Manba'ul 'Ulum Dukupuntang-Cirebon dengan nilai rhitung lebih besar dari $\mathrm{r}_{\text {tabel, }}$ yaitu 0,786>0,4438 dengan taraf signifikansi 
5\%, makaterdapat hubungan antara aktifitas berpidato dengan kemampuan berbicara; (3) terdapat hubungan yang positif dan signifikan antara kemampuan menyimak dan aktifitas berpidato dengan kemampuan berbicara siswa kelas XI Madrasah Aliyah Manba'ul 'Ulum Dukupuntang-Cirebon dengan nilai rhitung lebih besar dari rtabel, yaitu $0,822>0,4438$ dan nilai signifikansi sebesar 0,000 yang berarti kurang dari $0,05(0,000<0,5)$ maka Ho ditolak. Artinya, bahwa ada hubungan antara kemampuan menyimak dan aktifitas berpidato dengan kemampuan berbicara. Dengan demikian, secara bersama-sama kemampuan menyimak dan aktifitas berpidato mempunyai peran yang penting dalam meningkatkan kemampuan berbicara Bahasa Arab siswa.

\section{Daftar Pustaka}

Alwi, Hasan. 2007. Kamus Besar Bahasa Indonesia. Jakarta: Balai Pustaka.

Anis, Ibrahim. 1972. Mu'jam al-Wasith. Al-Qahirah.

Arikunto, Suharsimi. 2010. Prosedur Penelitian Suatu Tindakan Praktik. Jakarta: Rineka Cipta.

Effendi, Ahmad Fuad. 2009. Metodologi Pengajaran Bahasa Arab. Malang: Misykat.

'Ilyan, Ahmad Fuad Mahmud. 1992. Al Maharat al Lughawiyyah: Maa Hiyatuha wa Tharaaiq Tadrisiha. Ar Riyadh: Daar al Muslim li Nasyr wa Tauzi'.

Marlina, Lina. 2015. Signifikansi Metode Langsung Dalam Pengajaran Maharat al-Kalam. El-Ibtikar, 4 (1).

Rosalina, Susi. 1991. Contoh MC Dan Pidato Praktis Lengkap Dengan Seminar. Surabaya: Amanan.

Saefuloh, Hasan. 2012. Teknik Pembelajaran Keterampilan Bahasa Arab. Cirebon: Nurjati Press.

Sudarmawati, Asep Yudha Wijaya. 2008. Berbahasa dan Bersastra Indonesia. Surakarta: Pusat Perbukuan Departemen Pendidikan Nasional.

Sugiyono. 2007. Metode Penelitan Pendidikan: Pendekatan Kuantitatif, Kualitatif Dan RED. Bandung: Alfabeta.

Supinah, Suhendar \& Pien. 1992. Bahasa Indonesia: Pengajaran Dan Ujian Keterampilan Menyimak Dan Keterampilan Berbicara. Bandung: 
Pionar Jaya.

Supriyadi, D. (2005). Pendidikan Bahasa Indonesia 2. Jakarta: Depdikbud.

Tarigan, Henry Guntur. 1986. Menyimak Sebagai Suatu Keterampilan Berbahasa. Bandung: Angkasa.

. 2013. Berbicara Sebagai Suatu Keterampilan Berbahasa. Bandung: Angkasa.

Maidar G, Arsjad \& Mukti U. S. 1988. Pembinaan Kemampuan Berbicara Bahasa Indonesia. Jakarta: Erlangga.

Wangi, Putri Pandan. 2010. Bukan Pidato Biasa. Klaten: One Books.

Zaenuddin, Rodliyah. 2013. Penggunaan Media Sederhana Dalam Pembelajaran Bahasa Arab. Cirebon: IAIN Syekh Nurjati Cirebon.

https://portal-ilmu.com/pengertian-tujuan-metode-pidato/ (diakses tanggal 14 November 2018).

http://akses-ilmu.blogspot.com/2012/05/definisi-pidato-jenis-tujuanmetode.html, (diakses pada tanggal 14 November 2018). 